\title{
Amadeus
}

International Multidisciplinary Journal IISSN 2525-8281

DOI: 10.14295/aimj.v4i8.78

\section{The Impact of Fires in Amazon Rainforest on Public Health}

Adrielle Silva Alencar ${ }^{1}$, Lívia Barbosa Taveira do Nascimento ${ }^{1}$, Matheus de Lima Garcia ${ }^{1}$,

Thayanne Moreira de Alencar de Sá Parente ${ }^{3}$, Welinagyla Correia Rolim ${ }^{1}$, Camila Bezerra Nobre ${ }^{2}$
Abstract: Brazil's public health situation is harmed in regions such as amazon rainforest in the face of natural disasters. Recently, the fires in Amazon region contributed to the growth of organic and psychosocial diseases index and to the increase of medical attendance numbers, generating high repercussions and concerns in this scenario.

Keywords: Public health, wildfires, natural disasters, respiratory tract disease, mental health.

\section{El Impacto de los Fuegos en la Selva Amazonica sobre la Salud Pública}

Resumen: La situación de salud pública de Brasil se ve perjudicada en regiones como la selva amazónica ante desastres naturales. Recientemente, los incendios en la región amazónica contribuyeron al crecimiento del índice de enfermedades orgánicas y psicosociales y al aumento del número de asistencia médica, generando altas repercusiones y preocupaciones en este escenario.

Palabras clave: salud publica, incendios forestales, desastres naturales, enfermedades del tracto respiratorio, salud mental.

\footnotetext{
${ }^{1}$ Academics of Medicine at the Faculty of Medicine Estácio de Juazeiro do Norte - FMJ. Juazeiro do Norte, Ceará, Brazil;

${ }^{2}$ Faculty of Medicine Estácio de Juazeiro do Norte - FMJ. Juazeiro do Norte, Ceará, Brazil;

${ }^{3}$ Medical Student at Faculty of Medicine Estácio de Juazeiro do Norte - Estácio FMJ - Ceará, Brazil. Main author: thayannemoreiraa@hotmail.com.
} 


\section{Introduction}

Since the Neolithic period, with agriculture development, human action generates fires that, as long as it is controlled, sustain the agricultural activity, while natural fires keep the ecosystem in balance. However, this practice recently has been the subject of political, social and economic discussion, when on August 10th, 2019, fires in the Amazon rainforest became wild and uncontrolled, making that day known as "Fire's Day" (Machado,2019). In this context, besides the sociopolitical inclination, and as much relevant, rises a new aspect deserving consideration: the health of native and nearby population facing such environmental circumstances (Barbosa,2019) .

In 2019, due to fires intensification between July and September, the Amazon rainforest appeared again as the theme for national and international news when the phenomenon intensified to which point it reached southeast cities from Brazil. This time, different from what occurred in 1998, when the largest fires were registered in Roraima state, a strong El Niño isn't the culprit, but it's the rises in deforestation concomitant with fires to clean areas destined for pastures and crops (Azevedo,2019)(Oliveira, 2019).

According to data registered by Program of Fires (Programa de Queimadas), from the National Institute for Space Research (Instituto Nacional de Pesquisas Espaciais INPE), the year of 2019 registered until that moment the largest fires in the last seven years and revealed a rise of $82 \%$ compared to the same period of 2018. Of 71.497 recorded fires, 34.278 where in Brazil and the state of Mato Grosso was the most responsible in the country with $19 \%$ of the fires. Apart from the Brazilian states like São Paulo, Mato Grosso do Sul, Rondônia, Roraima, Pará, Tocantins, Acre and Paraná, the episode affected other countries, like Paraguay, Bolivia, Argentina and Peru (Dantas,2019) (Org.,2019).

NASA, through its satellites, registered an increase in the fires across the regions in Amazon rainforest and in its respective Brazilian states that are part of it (NASA,2019). The duration and extension of the flames threat the elements of the flora, fauna and also the native communities, putting them in risk of extinction. Many native animals from the forest couldn't escape the fire and those that survived, besides complication by smoke inhalation, lost their natural habitat, becoming vulnerable to predators and to the environment itself (Daly, 2019). Also, distributed in approximately 148 different lands, about a million natives who live in the Amazon region and survive on extractive activities have lost their crops, houses and developed respiratory problems 
because of what happened. This scenario exhibits the environmental crisis from the fires and reveals the possible irreversible consequences, like species extinction and the drastic change in the lives of those who live in or near the forest (Roman, 2019).

Unlike what happens in urban centers, in which its atmospheric pollution is the result from chronic exposure, in the Amazon rainforest the fires represent a high magnitude exposure, for an average period of 3 to 5 months, with particulate matter (PM) ranging from 400 to $600 \mu \mathrm{g} / \mathrm{m}^{3}$, exceeding the superior concentration limits established by World Health Organization for 8 to 12 times (Alves, 2017), (Carmo et al, 2010). The burning of biomass emits significant amounts of polluting particles, among them stands out the particulate matter (fine particles) which has a higher atmospheric resistance than the coarse particles, in addition to possess a high potential of direct action on the respiratory system, especially in risk groups such as children, elderly people or those with lung or heart diseases (Silva et al, 2013).

These patients, as a consequence of transitory alterations in airway and the impairment of pulmonary function, may require further medical assistance because of a higher risk of death (Ribeiro, 2008), (Filho et al, 2017). According to data from the World Health Organization (WHO), around 8 out of 100 deaths by lung cancer are a result from exposure to this material, proving its capacity to cause genetic damage to lung cells, like modification in cell cycle, oxidative stress and then cell death. On top of everything, it is known that contact with this material is also responsible for over $5 \%$ of deaths caused by cardiovascular diseases and for 3\% of respiratory infections (Ribeiro, 2008) (WHO, 2009).

Admissions number in basic health units for complaints about dyspnea, dry cough, sore and burning throat and red eyes considerably increased, especially in the south of region where there are 3 of the 10 most affected regions by the fires. At the same time, there was an increase by $15 \%$ in the health costs in these regions (Dinarte et al., 2019).

The situation reflected in the residents' health support in the Amazon region because the medical appointments increased, and in Porto Velho (Rondônia), the daily demand got to 380 appointments. Beyond the difficulty in mobility and access already existing in the local, the rise in demand increases the costs with medical and hospital service, revealing a public health problem (Turbiani, 2019) (Andreoni, Londoño, 2019).

In the face of physical damage, material loss and life-threatening, the psychological effects can be devastating and, most of the time, are not identified as easily as organic 
diseases. Between the repercussions in mental illness, stand ou cases of post traumatic stress disorder (PTSD), anxiety, mood disorders and suicide (Barbosa, 2017).

In natural disasters, the risk of people developing PTSD (Post-traumatic stress disorder) in the 12 following months varies between 5 to $60 \%$, while in the general population it stays around 5 to $10 \%$. The high levels of anxiety manifest themselves as a consequence of the psychological trauma which, by impairment of the immune system, also affects the physical health. Other individual stressors related to a subsequent development of generalized anxiety disorder could contribute, and among these stand out damaged places, experience with life risk, death of relatives or acquaintances, work damaged or financial loss (Navarro-Mateu et al., 2017). Studies show that depression occurrence in these cases varies between $4.9 \%$ and $54 \%$, and could also manifest in weeks or months after the disaster and persisted for years. Risk factors associated with development of this condition after such events are the low level of education, the female sex, presence of religious belief and previous disorders (Tang et al., 2014).

\section{Final considerations}

The fires in the Amazon Rainforest have been an aggravating factor for the local population health, both in relation to organic diseases, especially respiratory problems, and to psychiatric disorders. Few studies were found that focus on the impact of fires in the mental health of the affected population, so it is a research field yet to be explored. It was noticed the need to enhance monitoring and prevention of fires in forest areas, for both the local fauna and flora preservation and for the possible impacts in organic and mental health of the population.

\section{References}

Alves, N. .O. (2017). Scientific Reports. Retrieved 07 September, 2017, from https://www.nature.com/articles/s41598-017-11024-3

Andreoni, M.; Londoño, E.. (2019). Amid Outrage Over Rainforest Fires, Many in the Amazon Remain Defiant. Retrieved 26, August, 2019, from https://www.nytimes.com/2019/08/26/world/americas/brazil-amazon-rainforest-fire.html. 
Azevedo, A. L. (2019). O Globo. Retrieved 23, August, 2019, from https://oglobo.globo.com/sociedade/historia-da-amazonia-esta-escrita-em-cinzas-23897321

Barbosa V. (2019). EXAME. Retrieved 25, August, 2019, from https://exame.abril.com.br/brasil/inferno-na-floresta-o-que-sabemos-sobre-os-incendiosna-amazonia

Barbosa, V. (2017). Os efeitos psicológicos devastadores dos desastres naturais. Retrieved 01, April, 2019, from https://exame.abril.com.br/ciencia/os-efeitos-psicologicosdevastadores-dos-desastres-naturais/.

Carmo et al.. (2010). Associação entre material particulado de queimadas e doenças respiratórias na região sul da Amazônia brasileira. Rev Panam Salud Publica , 27(1)

Daly, N. (2019). National Geographic. Retrieved 27 de agosto de 2019, from https://www.nationalgeographicbrasil.com/meio-ambiente/2019/08/incendios-amazoniaanimais-silvestres-queimadas-floresta-amazonica-brasil

Dantas, C. (2019). G1. Retrieved 20, August, 2019, from https://g1.globo.com/natureza/noticia/2019/08/20/amazonia-concentra-metade-dasqueimadas-em-2019.ghtml

Dinarte et al.. (2019). Queimada causa danos à saúde e faz multiplicar atendimento médico na região Amazônica. Retrieved 27, August, 2019, from http://cbn.globoradio.globo.com/media/audio/272420/queimadas-faz-dispararatendimento-medico-na-regia.htm.

Filho et al.. (2017). Spatial distribution of biomass burning and mortality among the elderly in a Brazilian Amazon region, 2001 - 2012 . Ciênc Saúde Coletiva, 22(1), .

G1. (2019). G1. Retrieved 25, August, 2019, from https://g1.globo.com/natureza/noticia/2019/08/25/focos-de-queimada-na-amazoniasuperam-a-media-historica-de-agosto-diz-inpe.ghtml

Machado, L. (2019). BBC. Retrieved 27, August, 2019, from https://www.bbc.com/portuguese/brasil-49453037

NASA. (2019). National Aeronautics and Space Administration - NASA. Retrieved 21, August, 2019, from https://www.nasa.gov/image-feature/goddard/2019/wildfires-in-thebrazilian-rainforest-creating-cross-country-smoke

Oliveira, E. (2019). G1. Retrieved 23, August, 2019, from https://g1.globo.com/natureza/noticia/2019/08/23/amazonia-em-chamas-o-que-se-sabesobre-a-evolucao-das-queimadas-no-brasil.ghtml

Ribeiro, H. (2008). Queimadas de cana-de-açúcar no Brasil: efeitos à saúde respiratória. Rev Saúde Pública, 42(2).

Roman, C. (2019). Instituto Socioambiental. Retrieved 23 August, 2019, from https://www.socioambiental.org/pt-br/noticias-socioambientais/isa-mostra-terrasindigenas-mais-afetadas-por-incendios-na-amazonia-brasileira. 
Silva et al.. (2013). Material particulado originário de queimadas e doenças respiratórias. Rev Saúde Pública, 47(2).

Tang et al.. (2014). A meta-analysis of risk factors for depression in adults and children after natural disasters. BMC public health, 14 (623).

Turbiani, R. (2019). Fumaça de queimadas é ameaça à saúde pública, alertam médicos. Retrieved 22, August, 2019, from https://www.bbc.com/portuguese/brasil-49430367.

Navarro-Mateu et al.. (2017). Post-Traumatic Stress Disorder and other mental disorders in the general population after Lorca's earthquakes, 2011 (Murcia, Spain): A cross-sectional study. PloS one, 12(7).

World Health Organization (WHO). (2009). Global health risks : mortality and burden of disease attributable to selected major risks. World Health Organization.

\section{How to cite this article (APA format):}

Alencar, Adrielle Silva; Nascimento, Lívia Barbosa Taveira do; Garcia, Matheus de Lima; Parente, Thayanne Moreira de Alencar de Sá; Rolim, Welinagyla Correia; Nobre, Camila Bezerra (2020). The Impact of Fires in Amazon Rainforest on Public Health. Am. In. Mult. J., February to May. (8) 5, 1-6.

Received: $11 / 11 / 2019$

Accepted: 01/15/2020 